УДК: 930.2(045)=191.2(477.5+476)

DOI: $10.31470 / 2518-7600-2018-6-153-181$

\author{
THE SOURCES OF STUDE OF THE MONETARY \\ CIRCULATION ON THE TERRITORY OF THE \\ UKRAINIAN COSSAK HETMAN STATE IN 1648-1764
}

\title{
ДЖЕРЕЛА ДОСЛІДЖЕННЯ ГРОШОВОГО ОБІГУ НА ТЕРИТОРІЇ КОЗАЦЬКОЇ ДЕРЖАВИ УКРӒ̈НИ- ГЕТЬМАНЩИНИ У 1648-1764 РОКАХ
}

Валерій Нечитайло,

аспірант кафедри суспільних наук, інформаційної та архівної справи

e-mail:

nechytailo.valerii@meta.ua ORCID 0000-0003-3301-3898 Центральноукраїнський національний технічний університет, пр.

Університетський, 8.

м. Кропивницький, Україна, 25000
Valerii Nechytailo,

post-graduate student of the

Department of Social Sciences, Information and Archival

Affairs

e-mail:

nechytailo.valerii@meta.ua

ORCID 0000-0003-3301-3898

Central Ukrainian National

Technical University, 8, Univertytetskyi Av., Kropyvnytskyi, Ukraine, 25000

\section{ABSTRACT}

The main sources that can be used in the study of the topic of the Ukrainian Hetman State monetary history during the period from 1648 to 1764 are: archival material, chronicles, old documental acts, ethnographic sources, coin treasures, museum collections, newspaper materials, Internet resources and private collections. Each of these sources has a different degree of the scientific usefulness and reliability, advantages and disadvantages. A considerable number of contemporary materials chronicle and ethnographic sources have already been investigated by Ukrainian scientists. State historical archives have a huge scientific potential. In particular, while investigating the funds of the Central State Historical Archive in Kyiv, we managed to establish new facts and 
make the further development in the study of the aspect of money counterfeiting in Ukraine in the XVIII century. Internet resources allow us to discover coins of previously untapped stamp varieties, as well as to expand our understanding of the already completed topography of the coin finds. Actuality in the modern numismatics is the introduction into the scientific circulation of new founded treasures and their store, as well as the research of the museum collections. Often the museum collections are formed at the expense of gifts of coins that were discovered in the same historical area made by the local residents, which defines the collections of historical and local lore museums as highly informative in studying the monetary circulation. This especially applies to the museums located within the geographic boundaries of the Hetman State, as well as those coins and treasures that were excavated and transferred to other museums. Unsigned by most of the previous researchers are treasures that have been reported on the pages of the old newspapers periodicals. So we managed to find out the messages about the coins treasures of the investigated period on the pages of Ukrainian newspapers before the Soviet period and modern times. As for private collections, it is worthwhile introducing them into a scientific circle with some caution, considering that, unfortunately, not all collectors, selecting the collections, fix important information for scientists.

Keywords: Hetman State, monetary circulation, source of the study, historical archives materials, treasures, newspapers publications, museum collections.

Постановка проблеми. Період Гетьманщини у вітчизняній історії є надзвичайно важливим етапом розбудови української державності. Початком фінансової експансії Московії на українські землі є середина XVII століття, оспівана радянськими істориками як повернення України до Росії та порятунок недосконалого грошового ринку від європейської монетної системи, і початок повного панування, нарешті, московської монети. Фактично влада Московії використовувала українські землі як майданчик для проведення невдалих економічних експериментів, зокрема із впровадження неповноцінної монети, а також грошових реформ iз 
примусовим завищеним курсовим співвідношенням монети проти їх реальної вартості. Поразка визвольних змагань Івана Мазепи на початку XVIII століття надовго та кардинально змінила життєвий устрій населення, зміни відбулись в фіскальній системі, а також і в грошовому господарстві країни - посилився процес експансії московської монети на Україну. Дійсна історія її впливу та побутування є особливо актуальним у фокусі сучасної агресії Російської Федерації проти України на Сході нашої держави, адже різноманітні методи спроб впливу на українське державотворення, в тому числі і власної ефективної грошової системи, викликали у московської влади занепокоєння ще за часів Хмельниччини.

Аналіз останніх досліджень. Комплексному вивченню джерел 3 дослідження історії грошового обігу Гетьманщини вітчизняними та зарубіжними вченими не було приділено повноцінної та належної уваги. Науковий потенціал монетних скарбів у фокусі дослідження зазначеної теми визначено у творі О. Бакальця (Бакалець, 2007), також дослідником надано подальшого розвитку розвідкам матеріалів літописів, що започатковано було ще В. Шугаєвським (Шугаєвський, 1911) та М. Котляром (Котляр, 1971). Вивченню матеріалів щодо скарбів Київщини за документами державних архівів присвячене дослідження О. Бєлої (Бєлая, 2013). Важливість та високу інформативність використання монетних знахідок у історичному дослідженні аргументував В. Шугаєвський. Дані архівів активно вводились в науковий обіг М. Котляром (Котляр, 1981), В. Рябцевичем (Рябцевичь, 1969), М. Смірновим (Смірнов, 1993) та І. Сінчуком (2005). На прикладі матеріалів розкопок місця битви під Берестечком, Р. Шустом вивчені нумізматичні знахідки 3 гаманців козаків війська Б. Хмельницького. Інформаційний потенціал WEB-ресурсів встановлено В. Орликом (Орлик, 2013), що продовжила вивчати О. Шпортун (Шпортун, 2016). Численні етнографічні спогади про скарби, заховані козаками, занотовані ще у XIX столітті М. Сементовським (Сементовский, 1857). Музейні колекції, зокрема скарби, досліджено у різних музейних установах К. Поворознюк (Поворознюк, 2010), О. Попельницькою (Попельницька, 2004), З. Зразюк (Зразюк, 
2009), Р. Яушевою-Омельянчик (Яушева-Омельянчик, 1996). Використання матеріалів приватних колекцій є поширеним у наукових дослідженнях, але неточності, допущені в роботах О. Бакальця (Бакалець, 2004) змушують більш ретельно та обережно використовувати цей вид історичного джерела через відсутність достовірних та точних свідчень про процес комплектування тієї чи іншої колекції.

Метою статті $є$ визначення основних джерел що можуть бути ефективно використані у дослідженні теми історії грошового обігу Гетьманщини у 1648-1764 pp., окреслення ступеня інформативності кожного джерела та переваг i недоліків їх використання.

Виклад основного матеріалу. Основними джерелами вивчення зазначеної теми є: матеріали архівів, літописи, актові матеріали, етнографічні джерела, скарби, матеріали музейних колекції, газетні матеріали, Інтернет-ресурси та приватні зібрання.

Як справедливо зауважив відомий український вчений Микола Федорович Котляр, дослідники нумізматики зрідка звертаються до архівних джерел, досліджуючи переважно безпосередньо монетний матеріал (Котляр, 1981: 3), інакше кажучи - максимально використовують монети як історичне джерело, не підкріплюючи отримані висновки даними архівів.

Відомості про діяльність монетного двору у СанктПетербурзі 3 другої половини XVIII ст. до сьогодення відображено у документах, що частково збереглись у фондах Центрального державного архіву Санкт-Петербургу, серед яких значна частина була втрачена протягом наступних двох століть, - повідомляє у розвідці по історії даного архівного фонду M.І. Смірнов (Смирнов, 1993: 80-83). Іншим вагомим сховищем матеріалів з історії Гетьманщини, що знаходиться у Російській Федерації, є Центральний державний архів давніх актів у Москві, де зберігаються документи Малоросійського приказу, через який російський уряд здійснював владу в Україні. Зокрема, це фонд 124/1 «Малоросійські справи», що містить свідчення про податкову політику царського уряду щодо населення Гетьманщини, про збір податків до царської та гетьманської скарбниць, повідомляє Г. Швидько (Швидько, 1996: 89-92). 
Значення архівних джерел у контексті історії грошового обігу та скарбознавства Київщини всебічно окреслені у дослідженнях відомої української архівознавеці О.М. Бєлої (Бєлая, 2013: 189-194). Щодо монет досліджуваного періоду вчена повідомляє про наявність у фонді № 442 ЦДІАК «Канцелярія Київського військового, Подільського та Волинського генерал-губернатора» свідчень про знахідки московських дротових копійок, а також утримання московським урядом військового гарнізону у Верхньому місті та видачу їм жалування московськими копійками (Бєлая, 2013: 193).

Результатом грунтовного дослідження М. Котляра щодо системи грошової лічби в Україні у XIV - XVIII ст. стали вирахувані на основі аналізу архівних джерел грошові курси монет 3 різних грошових систем на Правобережній та Лівобережній Україні, періоди коливання монетної стопи та кількості монет в обігу, уточнення нумізматичних термінів та назв монетних номіналів у повсякденному житті населення (Котляр, 1981: 4). Але варто зазначити, що впродовж останніх 20 років кількість відомого дослідникам монетного та скарбового матеріалу суттєво зросла за рахунок несанкціонованого використання пошуково техніки, що дозволяє по-новому поглянути на загальну картину грошового обігу Модерної Доби, уточнити раніше висловлені теорії, перевірити їх та врахувати допущені неточності. Далі ми наведемо низку уточнень спірних тверджень в роботах дослідників «класиків», що, звісно, не зменшить ролі фундаментальних досліджень у вітчизняній історіографії, але дозволить суттєво уточнити окремі проблемні питання в історії грошового обігу України в окреслений часовий період. Тому погоджуючись із позицією М. Котляра щодо важливості побудови нумізматичних досліджень на архівних джерелах та негативного впливу на результати використання лише суто нумізматичних джерел, ми все ж таки, загостримо увагу на недоліках використання суто архівних джерел без проведення паралелей із даними аналізу власне монет.

I.I. Сінчуком на основі дослідження матеріалів Московського архіву Міністерства Юстиції вдалось додатково 
підкреслити домінуючу участь польсько-литовських півтораків на Україні після 1650 р. в умовах поступової окупації грошового ринку московською монетою (Синчук, 2005: 201).

Під час дослідження та складення топографії скарбів, Зінаїдою Зразюк було використано також матеріали архіву Національного музею історії України та Архіву ВУАКу (Зразюк, 2009: 159).

В.Н. Рябцевичем у дослідженні обігу мідних монет другої половини XVII ст. використано справу у фонді ЦДІАК (в часи дослідження вченого - Центрального державного архіву Української РСР у Києві - ВН), де повідомляється про знахідку скарбу 31 фунту мідних монет Олексія Михайловича у руїнах церкви Св. Ірини (Рябцевич, 1969: 434).

Фонд Генеральної військової канцелярії (ЦДІАК. Ф 51. О. 3. С. 125. Арк. 4-10), що нині зберігається у Центральному державному історичному архіві України у Києві в контексті iсторії грошового обігу комплексно досліджено М.Ф. Котляром. Проаналізований архівний матеріал дав змогу вченому дослідити та всесторонньо висвітлити аспект підробки грошей в Україні в першій чверті XVIII ст. (Котляр, 1981: $205-$ 209). В згаданому фонді ЦДІАК містяться також свідчення про тогочасних фальшивомонетників: у 1724 р. було затримано та відправлено до Глухова жителів міста Келеберди - Дениса Криворутченка (ЦДІАК. Ф.51. О.3. С.1337. Арк. 1-4) та Дениса Сементовича (ЦДІАК. Ф.51. О.3. С.1353. Арк. 1-7). В Полтавському полку фальшивомонетників було затримано також у 1731 р. в Старих Санжарах та вислано до Сибіру (ЦДІАК. Ф.51. О.3. С.3950. Арк.1-9). У 1723 р. на ярмарку в Миргороді було затримано фальшивомонетників (ЦДІАК. Ф.51. О.3. С.1103. Арк.1-16.). У фонді Генеральної військової канцелярії містяться також свідчення про офіційні заходи боротьби державної влади, спрямовані проти фальшивомонетників. Так, у 1723 р. наказним гетьманом Павлом Полуботком було надіслано чернігівській полковій старшині універсал про необхідність вилучення фальшивих монет з обігу (ЦДІАК. Ф.51. О.3. С.1077. Арк. 1-2.).

Вагому цінність літописів у вивченні історії грошового обігу Гетьманщини відмітив та проаналізував М.Ф. Котляр 
(Котляр, 1971: 1-174). Густинський, Межигірський та Острозький літопис в контексті джерел у вивченні історії грошового обігу Гетьманщини висвітлено О. Бакальцем (Бакалець, 2004: 218-232). Г. Козубовським почерпнуто із літопису Самійла Величка про джерело отримання гетьманом Б. Хмельницьким сировини для виготовлення власної монети - із дорогоцінних металів, здобутих в якості трофею після перемоги під Жовтими Водами (Козубовський, 2001: 39).

Безперечним джерелом дослідження історії грошового обігу будь-якого регіону та історичного періоду є скарби, що неодноразово підтверджувалось відомими дослідниками. Зокрема, підсумки та перспективи дослідження скарбознавства всебічно та якісно представлено відомим українським вченим Віктором Петровичем Коцуром (Коцур, 20147: 15-32). Згідно твердження М.Ф. Котляра, саме «нерозвиненість товарного обігу, панування натурального господарства доби феодалізму сприяли тому, що повсюду гроші випадають у скарби» (Котляр, 1981: 5). Доповнити влучну тезу вченого можна лише тим, що в Україні в досліджувану добу відчувалась слабка розвиненість банків та інших фінансово-кредитних установ, що негативно відображалось на розвитку економіки. Також через відсутність для населення стабільних фінансовій інституцій і можливості вкладення власних грошей, єдиним надійним та досить традиційним способом збереження статків було ховання їх у землю. Ускладнювали ситуація і постійні війни, що руйнівними хвилями прокочувались українською землею.

Вірною є теза Р. Шуста про скарби, які «...є своєрідними зразками монетної маси, яка на момент випадання з обігу (відкладення монет у землю, в дупло дерева, тощо), обслуговували потреби грошового господарства» (Шуст, 2005: 214).

Особливу роль у фокусі скарбознавства посідають монетні скарби із вмістом до їх складу немонетних часток, що спроможні датувати включені до них вироби: прикраси, елементи одягу та ін. (Попельницька, 2004: 204).

Знаний українській нумізмат Валентин Шугаєвський справедливо також зазначив, що окрім даних щодо датування археологічних пам'ятників та сторінок економічної історії, 
нумізматичні скарби слугують важливим джерелом по визначенню заселеності тієї чи іншої місцевості в конкретну історичну добу (Шугаевский, 1911: 17).

Самі скарби є археологічним джерелом. Українським вченим Г. Козубовським цілком справедливо вказано про те, що лише комплексні та ретельно сплановані археологічні пошуки в Лисянці, Чигирині та Торговиці спроможні наблизити нас до відповіді на питання - чи була в Україні власна гетьманська монета? (Козубовський, 2001: 38).

Важливим при аналізі скарбів $\epsilon$ також i метод розкладання монет та їх пакування всередині скарбу. Щодо цього I. Сінчуком вдало використані мемуарні джерела, що свідчить про розкладання монет у рулони та свитках, що зафіксовано джерелами XVII-XIX ст. (Синчук, 2005: 201).

Як вагоме історичне джерело у вивченні грошового обігу Гетьманщини визначив монетні скарби О.А. Бакалець (Бакалець, 2007: 1-15). При цьому Олексієм Андрійовичем в якості новизни свого дослідження вказано на першість його у визначенні ролі скарбів в якості історичного джерела (Бакалець, 2007: 10), ігноруючи при цьому праці його попередників - О.Бєлої (Бєлая, 2013: 189-194) та О. Попельницької (Попельницька, 1999: 59).

Досліджуючи монетні та монетно-речові скарби, О. Попельницька зробила висновок про те, що більшість скарбів XVII ст., виявлених на Черкащині, можна віднести до захованих під час подій Національно-визвольної війни українського народу під проводом Б. Хмельницького (Попельницька, 1999: 59). Безумовно, таке датування є правильним в разі відсутності в складі скарбу монет після 1654 p.

В нумізматичній літературі відомі й етнографічні свідчення про скарби, зафіксовані краєзнавцями зі слів козаків, що приймали участь у Коліївщині, що передавали із вуст в уста згадки про заховані предками скарби. Таким цікавим, з наукової точки зору, етнографічним джерелом $є$ рукопис М. Сементовського (мовою оригіналу) «...в каких именно местах и какие сокрыты клады Гаймамаками и местными жителями», опублікована в Києві у 1857 р. Загалом рукопис 
наповнено досить неправдоподібними свідченнями про скарби, яких, скоріше за все, або зовсім ніколи не було, або про їх знаходження вказане фантастичне неіснуюче місце, або навіть в разі вказівки про достовірне місце знаходження того чи іншого скарбу, його було віднайдено та привласнено у тому ж XIX ст. Але складене М Сементовським видання містить цінні відомості про ємності скарбів, в яких ховали гроші, тобто діжечки, шкіряні гаманці, горщики, казанці та котли, покриваючи зверху тканиною, навіть власною одежею (Сементовский, 1857: 15). Загалом більша частина згадок називає скарб як «здобич», рідко вказуючи які саме монети заховано. У згадці № 108 вказано про схованку «два мішки грошей, один з рублями, а іншій грошовий» (Сементовский, 1857: 5). Також згадка № 115 вказує на схованку «зтала дукатов» (Сементовский, 1857: 8). Із цих свідчень бачимо, що в усних переказах вказана або найпоширеніша для тогочасного населення одиниця обрахунку - «рубль», або для збільшення ефекту від цінності скарбу застосовано колись вартісні та цінні золоті дукати.

Про інше етнографічне джерело згадує в своїй розвідці Г Козубовський, цитуючи зібрані перекази Марком Грушевським з села Суботова у 1897-1899 рр.: «А щзо кладi Хмельницького є багато у землі, то є...На шляху...виносить водою гроші, дукачі, намиста...Гроші $\epsilon$ з з баввонцем у короні - се мабуть польські позоставались, а то все з козаком на коні з пікою - все вже, мабуть, виробка часу Хмельницького. $Є \check{u}$ гетьман з булавою на деяких. Махей Трегуб старий, Топчій, розказує, щзо як козакував у лісі...та бачив знайшли у Тіньках люди Хмельницького грошей золотих чимало й по проваллях $i$ по ямах увалених то по могилах і у Суботові. Та се кісь инчі були - тоненькі, як луска з риби і жовті все - мабуть давніші се, бо за Хмельницького золото як жар червоне все було, скіко не доводилось бачити ...» (Козубовський, 2001: 39).

До специфічного виду скарбів можна віднести прикраси, виконані із монет. Деякі із них можуть надати вивченню процесів історії грошового обігу нових фактів. Так, опубліковане А. Бойко-Гагаріним намисто із с. Гущинці Калинівського району Вінницької області свідчить про 
проникнення шостаків Яна II Казимира на Поділля та курсування їх одночасно із монетами Сигізмунда III Ваза (Бойко-Гагарін, 2014: 48).

Досліджуючи скарбові комплекси, варто приділяти ретельну увагу точності ідентифікації монет. Так як вмістити в публікацію фото всіх монет із скарбу часто є неможливим, точність і правильність визначення монет $€$ надзвичайно актуальним (без помилок, опечаток, з урахуванням деталей). Так, у опублікованому О.А. Бакальцем скарбі монет XVII ст., знайденого неподалік міста Бар Вінницької області (Бакалець, 2004: 17), помітні суттєві неточності. Публікатором наводиться у вмісті скарбу шостак Речі Посполитої 1614 р., в той час як в цьому році карбування шостаків не проводилось, а у депозиті скоріше за все присутній шостак 1624 р. Також Олексієм Андрійовичем вказується на наявність півтораків карбування Кракова, Бидгоща та Вільно у складі Барського скарбу. Звісно, всі перераховані монетні двори карбували півтораки в часи правління Сигізмунда III Вази (також у монетному господарстві у 1620 р. був задіяний монетний двір у Ризі), але емісії Віленського монетного двору 1619-1920 рр. є досить рідкісними, тому в нас виникає сумнів щодо реальної наявності їх у складі описуваного скарбу.

Дійсно, вміст деяких відомих науці скарбів 3 певних причин може вважатись сумнівним. Не говорячи про можливу високу імовірність отримання хибних даних від осіб, що знайшли скарб, особливо сьогодні, коли більшість власників скарбів остерігаються отримання такої інформації іншими скарбошукачами, що продовжать пошуки у місці знахідки сумніви можуть виникнути і при обробці офіційно знайдених скарбів. Так, дослідником К.В. Поворознюком вказано на історію вивчення скарбу із колекції ХОКМ, знайденого в околицях с. Попівці Летичівського району на Хмельниччині. Публікатор повідомляє, що відомий український вчений Владлен Анохін виявив у складі скарбу окрім монет XVI-XVII ст. також частину монет XVIII-XIX ст., припускаючи при цьому, що скарб таки міг з часом доповнитись більш пізніми монетами до ранніх, що зберігались «як спадок» (Поворознюк, 2010: 98). Очевидно, що таку версію слід вважати сумнівною, 
а потрапляння монет на стільки різних епох результатом помилки та недбальства зберігачів. На високу імовірність помилки вказує і факт допущення численних неточностей в описах та легендах монет 3 комплексу, допущених публікатором скарбу. На непрофесійну обробку скарбу вказує $\mathrm{i}$ виявлення після проведення контролю пробірної інспекції монет 3 недорогоцінного металу, що дослідники віднесли до часу правління Сигізмунда III Ваза (Поворознюк, 2010: 102). Імовірно, що до рук археологів потрапили тогочасні підробки монет, що при первинному обстеженні монет скарбу не було уточнено.

Нажаль, в наші часи потрапляння скарбів у повному обсязі та зі збереженими всіма монетами є великою рідкістю, а такі монетні комплекси на сьогоднішній день грають високу роль та мають величезну актуальність у уточненні раніше отриманих класиками нумізматики висновків. Так, опублікований О. Бакальцем скарб, знайдений в околицях с. Велика Бушинка Немирівського району Вінницької області в повному обсязі потрапив до фондів Вінницького обласного краєзнавчого музею (Бакалець, 2009: 200).

Тому наступним джерелом у вивченні теми ми розглянемо монети та скарби, що зберігаються в музеях.

Найбільшою популярністю серед нумізматів, чи то науковців чи колекціонерів, користується відомий в Україні інтернет-ресурс «Violity», високе значення для наукових досліджень якого відмічено О. Шпортун (Шпортун, 2016: 125-127).

Невід’ємним у процесі наукових пошуків є дослідження найбільш значимого джерела - самих монет.

Окрім монет, що зберігаються у колекціях державних музеїв, в умовах сьогодення важливу роль посідають і монетні знахідки, що стали доступними внаслідок їх виявлення приватними пошуковцями із застосуванням точної пошукової техніки. Ми підтримуємо позицію Віктора Петровича Коцур щодо необхідності фіксації таких знахідок та введення їх до наукового обігу (Коцур, 2013: 5).

В процесі використання музейних матеріалів дослідники часто зіткаються із певними організаційними та 
бюрократичними складнощами, викликаними особливостями музейного зберігання та фондової роботи. Так, на момент написання монографії М.Ф. Котляру були недоступні скарби із Національного музею історії України через його переїзд у інше приміщення, що стало причиною відсутності в роботах вченого, присвячених топографії скарбів та монетних знахідках низки даних (Яушева-Омельянчик, 1996: 101).

Досліджуючи історію грошового обігу Гетьманщини, О. Бакалець описав колекції та фонди музеїв, що територіально розміщені на досліджуваній території сьогодні - Вінницький краєзнавчий музей, Глухівський історичний музей, Кам' янецьПодільський історичний музей (Бакалець, 2004: 6).

Монети з фондів Білоцерківського краєзнавчого музею опубліковані Л.С. Башинською (Башинська, 2015: 105-115). Враховуючи той факт, що всі нові надходження монет до колекції музею передані місцевими жителями із випадкових знахідок на околицях, можна вважати новітні надходження до БКМ досить цінним історичним джерелом у процесі вивчення особливостей історії грошового обігу Київщини.

Додатковим матеріалом для вивчення теми можуть слугувати торгівельні пломби. Про торгівельні європейські зв'язки Гетьманщини із країнами Західної Європи свідчить знахідка торгової пломби міста Бреслау, виявленою археологами при розкопках Цитаделі у замку в Батурині (Желіхівська, 2013: 13).

Додатковим джерелом у вивченні питань історії грошового обігу, зокрема знахідок монет, є газетні видання.

Так, знахідки монет, про які було повідомлено в газеті «Киевлянин» у 1869 р. було використано у складеній М.Ф. Котляром топографії. В. Антонович, процитувавши звістку про цей скарб монет середини XVII ст., також опублікував матеріал. У складеній М. Сементовським рукописі щодо переказів про скарби, про яку згадувалось вище, повідомляється про перепублікацію інформації про знахідки скарбів у газеті «Київські Губернські Відомості» (Сементовский, 1857: 19).

Свідчення про нові скарбові знахідки нам вдалось виявити у дорадянських газетах українських губерній, що дає 
змогу ввести у науковий обіг данні про нові скарби. Наведемо найяскравіші приклади знахідок з території Гетьманщини.

16 травня 1915 р. вінницька газета «Південно-Західний край» повідомляе про знахідку: «Полтава. $14 \mathrm{~V}$. У Миргородському уїзді знайдено скарб монет часів польських королів, переважно Сигізмунда третього» (Кладъ. ЮгоЗападный Край).

9 червня 1913 р. кам'янець-подільська газета «Подолянин» повідомляє про знахідку скарбу: «У Стасях, Полтавського уїзду, знайдено скарб з 2350 польських та німецьких срібних та мідних монет початку XVII століття» (Кладъ. Подолянин). Судячи із наявності у складі скарбу мідних монет, можна припустити, що редакторами газет було допущено помилку і тезаврація із села Стаси сучасного Диканського району Полтавської області датується другою половиною XVII ст.

Київська газета «Київські вісті» повідомляє 29 жовтня 1909 р. про знахідку скарбу в околицях села Великий Самбор Конотопського району Сумської області: «Скарб. У с. Великий Самбор Конотопського у., Черн.губ. козак Олександр Коваль, копаючи у дворі яму, викопав на глибині одного аршину глечик із старовинними монетами не російського походження, числом 600 штук. Глечик в якому знаходився скарб, зачеплений лопатою, розшукався. Знайдений скарб иілком відправлений губернській владі у Чернігів» (Кладъ. Киевские вести).

Про знахідку значного за кількістю депозиту московських дротових монет повідомляє «Кіевлянин», публікуючи інформацію про археологічні розкопки А.К. Хребтова у печерах Межигір'я (сучасний Вишгородський район Київської області): «...в головній галереї печери, на відстані сажені від ї̈ кіния, на глибині чвертей двох-трьох знайдено глиняний горщик сповнений срібними монетами до-Петровського періоду, кількістю більше 1500 штук. Все цее переправлено до Iмператорської археологічної комісіӥ» (Открытие новых пещер в Межигорье. Киевлянин).

Про найновіші сучасні пошуки при реконструкції Поштової площі в Києві та знахідки мідних солідів Яна II Казимира повідомила О. Байвидович в столичній газеті «Вести» (Байвидович, 2015: 3). 
Як бачимо, більшість заміток в газетах не вказує широкі деталі знахідок та містять певні неточності, що викликає необхідність обережно ставитись до подібного джерела. Але газетні публікації містять і корисні свідчення, приблизну ідентифікацію монет їх кількість, їх вмістилище та інколи навіть ім'я особи, що знайшла скарб та при яких обставинах. 3 іншого боку, газетні замітки можуть містити раніше не введені в науковий обіг дані та суттєво розширити топографію, відому на сучасному стані дослідження. Привертає увагу факт чіткого акценту газетних заміток на приналежність монет до російських чи іноземних емітентів, явно відчувається відтінок бажання перевищити роль всього російського в тогочасній пресі, що, повністю логічно, викликане вимогами часу публікації цих повідомлень.

Віктором Петровичем Коцуром комплексно та влучно аргументовано необхідність введення до наукового обігу нових знахідок монет з числа приватних пошуків (Коцур, 2016: 11-14). Василем Михайловичем Орликом вдало підкреслено значний науковий потенціал використання в нумізматичних дослідженнях електронних ресурсів (Орлик, 2013: 129-133).

У процесі дослідження історії грошового обігу повсталої держави України-Гетьманщини використовуються Інтернетресурси, до яких відносяться: аукціони та форуми «Violity», «New Auction» та «Unc.ua», електронна енциклопедія «Вікіпедія», соціальна мережа для науковців «Academia.edu», соціальна мережа «Facebook», а також приватні канали на «Youtube». Кожен із зазначених сервісів має свої як переваги, так і недоліки. Користуючись Інтернет-ресурсами, нам вдалось виявити нові дані для нумізматичної науки, зокрема визначити та зафіксувати раніше неопубліковані різновиди монет Петра I, що виявлені на території Гетьманщини, ввести до наукового обігу нові знахідки тих монет, що вважались рідкісними у знахідках України попередниками у вітчизняній науковій нумізматичній історіографії.

Дослідницею О. Шпортун проведено аналіз низки сайтів із нумізматичним змістом (говорячи професійною мовою «контентом»), із зазначенням, що нумізматичні сайти $\epsilon$ ресурсами в мережі Інтернет не лише комерційного та 
інформаційного характеру, а і наукового профілю (Шпортун, 2016: 174). Погоджуємось із позицією дослідниці в тому, що наявність більше ніж 500 тис. сайтів нумізматичної тематики на запит у системі «Google» свідчить про значний інтерес аудиторії до вивчення нумізматики та популярності іiі як спеціальної галузі історичної науки (Шпортун, 2016: 174).

Фактично найбільш популярним Інтернет-ресурсом, що відвідується любителями старожитностей, краєзнавцями та пошукачами скарбів є сайт «Violity» (Шпортун, 2016: 125-127). Згаданий Інтернет-ресурс охоплює широку аудиторію відвідувачів сайту як в Україні, так і далеко за їі межами, науковий потенціал матеріалів, що викладають приватні пошуковці на даному ресурсі давно відмічений і у сусідніх державах. Ресурс «Violity» фактично є також широко відомим брендом. «Violity» складається із Форуму - місця, де зареєстровані учасники не залежно від країни реєстрації мають можливість обговорювати ті чи інші проблемні теми, а також 3 Аукціону - ділянки з продажом товарів.

Популярними серед користувачів мережі Інтернет є також електронні аукціони, що не мають в системі майданчиків для обговорення предметів старовини, такі як: «New Auction» (Аукціон New Auction) i «Unc.иa» (Аукціон UNC). До позитивних сторін згаданих ресурсів варто віднести можливість зворотного зв'язку для уточнення місць та обставин знахідки монет, що відносяться до тематики наукового дослідження, збирати фотографії для подальшого іконографічного та штемпельного аналізу монет, тощо. Серед недоліків зазначених ресурсів варто віднести поширену помилкову думку та переконання щодо дійсної історичної періодизації, коли багато користувачів сайтів називають монети Нового часу середньовічними. Слід відмітити, що і структура гілок аукціону побудована нерідко у різних ресурсах у відповідності до такої самої хибної думки. У користуванні цими ресурсами приваблює можливість сортування по металу, по оригінальності та ціні. На обох сайтах завантажено одночасно майже 100.000 монет. Скориставшись пошуковими системами зазначених ресурсів, ми встановили, що цілих чи частково розділених скарбів у продажі на цих майданчиках не було. 
Високу популярність та відвідуваність має електронна енциклопедія «Вікіпедія». Вона має свої як позитивні, так i негативні аспекти. До позитивних рис можна віднести іii безкоштовність, доступність всіма світовими мовами, можливість створювати сторінки 3 інформацією як про історичні події, терміни та регіони, а також присвячені персоналіям, надавати покликання на джерела. Але головним недоліком такої інформації є іiі, так би мовити, «всенародна» організація, коли ії наповнюють та модерують люди по всьому світу, що в разі відсутності професійного моніторингу профільних тем фахівцями призводить до проникнення в науковий обіг неперевіреної та часто хибної інформації. Нагадаємо, що з-посеред наукової спільноти давно склалось уявлення про небажаність покликань на матеріали «Вікіпедії» у серйозних наукових дослідженнях. Неточності та суттєву неповноту завантажених до згаданої енциклопедії даних ми виявили і у відношенні до досліджуваної теми - проблем грошового обігу Гетьманщини. Так у «Вікіпедія»є загально оглядова стаття про історію Гетьманщини, або Війська Запорозького Гетьманщина або Військо Запорозьке, а також про розвиток іiі економіки (Економіка Гетьманщини). Але обидві ці сторінки комплексно та навіть поверхнево не висвітлюють всю складність i багатогранність грошового обігу доби Гетьманщини, а також процесів окупації їі грошового ринку та постійних експансії з боку Московії. Частково цю сторінку фінансово-економічних відносин Гетьманщини та Московії висвітлює стаття «Севский чех» (Севський чех), присвячена емісії у 1686 р. на монетному дворі у місті Севську імітації монет Речі Посполитої, що несли на своєму полі імена московських царів Іоанна та Петра Олексійовичів і їх матері регента - Софії, що мало на меті «привчити» населення України до московської монети, коли царська влада вважала вже наявний грошовий обіг, монети в Україні європейсько якісними та сучасними з технологічної точки зору. У замітці лише поверхово визначено історію введення цієї монети до обігу, надано зображення лише ii аверсу, а також вказано помилково сучасну адміністративну область, в якій знаходиться м. Севськ, насправді в Брянській, а не Орловській області 
сучасної РФ (Шуст, 2012: 503). Також на сторінці із зазначеною статтею надано якісну ілюстрацію чеха 1686 р. 3 колекції Національного музею історії України (Бойко-Гагарін, 2016: 16-18).

Високо інформативним ми відмічаємо популярну у світі соціальну мережу Academia.edu. Вона створена для науковців, що готові ділитись своїми досягненнями та публікаціями 3 дослідниками у всьому світі. В мережі наявні як приватні сторінки вчених, так і сторінки груп, об'єднаних за тематикою дослідження. На жаль, окремої тематики для вивчення історії Гетьманщини в зазначеній мережі немає.

Вважаємо, що попри наявні недоліки, особливості та певні небезпеки у використанні, електронні WEB-ресурси всеж мають вагомий інформаційний i науковий потенціал у вивчення особливостей грошового обігу Гетьманщини, введення до наукового обігу фактів та нових даних, що допоможуть виявити раніше невідомі сторінки цього періоду в історії України, а також конкретизувати вже частково висвітлені моменти.

Досліджуючи інформаційний потенціал електронних ресурсів в фокусі використання їх в нумізматичних дослідженнях, О. Шпортун було вдало зазначено корисність у цьому контексті соціальних мереж (Шпортун, 2016: 175). Зараз найбільшу популярність серед них отримав «Facebook». Перевагами мережі «Facebook» $є$ зручність у користуванні та швидкість поширення інформації, розсилання будь-яких новин засобами приватних повідомлень тощо. Корисними в нумізматичних дослідженнях можуть виявитись не лише персональні сторінки нумізматів, що викладають в «Facebook» окремі результати своїх наукових пошуків, а і сторінки нумізматичних товариств, музеїв, торгівельних майданчиків в цій мережі.

Важливість дослідження золотих монет із приватних зібрань в Україні вдало зауважив академік Віктор Коцур, справедливо аргументуючи позицію тим, що більшість золотих монет XVI-XVIII ст. у сучасних нумізматичних зібраннях вітчизняних колекціонерів походять зі знахідок України i вимагає ретельного вивчення (Коцур, 2016: 19). 
Дослідження приватної колекції краєзнавця та знавця історії Поділля П.І. Січенка вдало використав у своєму дослідженні О. Бакалець, адже всі вивчені монети відносяться до знахідок із даного регіону (Бакалець, 2004: 21). Але до складу приватних колекції та до інформації щодо походження монет із знахідок тієї чи іншої місцевості варто відноситись досить обережно. Так, у роботах О. Бакальця є введена до наукового обігу ніби із знахідок Поділля рідкісна російська копійка 1718 р., що належить приватному колекціонеру (Шпортун, 2016: 175). Судячи із візуального аналізу фотографії, наданої у публікації, ця монета із високим ступенем імовірності $\epsilon$ антикварною підробкою. Прикро, що дана антикварна підробка цитується дослідником і в подальших своїх працях, присвячених історії грошового обігу українських регіонів (Бакалець, 2006: 21).

До речі, це не єдина антикварна підробка, введена до наукового обігу О.А. Бакальцем. Опублікована як унікальна знахідка копійка Катерини I, ніби знайдена неподалік міста Кременчук 3 високим ступенем імовірності $\epsilon$ також антикварною підробкою, неодноразово цитованою дослідником у власних працях. При тому ж, Олексій Андрійович у висновках до своєї публікації все ж наводить декілька аргументів на користь імовірності віднесення опублікованої монети до антикварних підробок, але висвітлює їx 3 позиції підвищення важливості публікації цієї знахідки як рідкісної та унікальної для українського грошового обігу, говорячи: «По-перше, 1 мідна копійка серійно взагалі не випускалась у 1727 р. ...По-сьому, в жодному з каталогів XIX mа XX cm. навіть не згадується вказана мідна копійка» (Бакалець, 2006: 22). На нашу думку, ці самостійно висунуті Олексієм Андрійовичем аргументи рідкості монети як раз слугують на користь їі визначення як антикварної підробки, про це свідчить також і візуальний аналіз наданої фотографії.

Висновки. Отже, ми встановили, що основними джерелами, що можуть бути використані у вивченні теми історії грошового обігу Гетьманщини у період з 1648 по 1764 pp., є: матеріали архівів, літописи, актові матеріали, етнографічні джерела, скарби, матеріали музейних колекції, 
газетні матеріали, Інтернет-ресурси та приватні зібрання. Кожне з зазначених джерел має різну ступінь наукової цінності та достовірності. Значна кількість тогочасних актових матеріалів, літописів та етнографічних джерел вже досліджено українськими науковцями. Значним науковим потенціалом володіють державні історичні архіви. Зокрема, досліджуючи фонди Центрального державного історичного архіву в Києві нам вдалось встановити нові факти та надати подальшого розвитку вивченню аспекту фальшивомонетництва в Україні у XVIII ст. Інтернет-ресурси дозволяють виявити монети раніше неописаних штемпельних різновидів, а також розширити наше уявлення про вже складені топографії знахідок монет. Актуальним в сучасній нумізматиці є введення в науковий обіг нових знайдених скарбів та їх склад, а також дослідження музейних зібрань. Нерідко колекції музеїв формуються за рахунок дарунків місцевих жителів з монет, що були виявлені в тій самій історичній місцевості, що визначає колекції історичних та краєзнавчих музеїв як високо інформативні у вивченні грошового обігу. Особливо це музейні заклади, розміщені в географічних межах Гетьманщини, а також ті монети та скарби, що були знайдені та передані до інших музеїв. Незафіксовані більшістю попередніх дослідників $є$ скарби, щодо яких повідомлялось на сторінках періодичної преси. Так, нам вдалось виявити повідомлення про скарби монет досліджуваного періоду на сторінках українських газет дорадянського періоду та сучасності. Щодо приватних колекції, варто із певною обережністю вводити їх в науковий обіг, зважуючи на те, що, на жаль, далеко не всі колекціонери, збираючи колекції, фіксують важливу для науковців інформацію.

\section{ДЖЕРЕЛА ТА ЛІТЕРАТУРА}

1. Центральний державний історичний архів України, м.Київ (ЦДІАК України). Фонд. 51. Опис. 3. Справа. 1103. Арк. $1-16$.

2. ЦДІАК. Фонд. 51. Опис. 3. Справа. 1077. Арк. 1-2.

3. ЦДІАК. Фонд. 51. Опис. 3. Справа. 1337. Арк. 1-4.

4. ЦДІАК. Фонд. 51. Опис. 3. Справа. 1353. Арк. 1-7. 
5. ЦДІАК. Фонд. 51. Опис. 3. Справа. 3950. Арк. 1-9.

6. ЦДІАК. Фонд. 51. Опис. 3. Справа. 125. Арк. 4-10.

7. Кладъ. Юго-Западный Край. 16 травня 1915 року. № 110. Вінниця, 1915. С. 3.

8. Кладъ. Подолянин. 9 червня 1913 року. № 783. Кам’янецьПодільський, 1913. С. 2.

9. Кладъ. Киевские вести. 16 (29) жовтня 1909 р. № 275. Київ, 1909. С.4.

10. Открытие новых пещер в Межигорье. Киевлянин. № 305. Киев, 1907. С. 4.

11. Байвидович О. На Подоле обнаружили русло и польские монеты. Вести. № 161 (561). 9 сентября 2015. Киев, 2015. С. 3.

12. Бакалець О.А. Велико-Бушівський скарб 2004 p. західноєвропейських монет XVII ст. Історико-географічні дослідження в Україні. № 11. Київ: Інститут історії НАН України, 2009. С. 200.

13. Бакалець О.А. Гроші та грошовий обіг на Поділлі XVIIXVIII ст. Спеціальні історичні дисципліни. № 13. Київ: Інститут історії НАН України. Київ, 2006. С. 121.

14. Бакалець О.А. Монетні скарби як джерело вивчення грошового обігу Гетьманщини (1648-1764 рр.).: автореф. дис. на здобуття наук. ступеня кандидата іст. наук: спец. 07.00.06. Київ, 2007. 15 с.

15. Бакалець О.А. Російська срібна копійка в грошовому обігу України II половини XVII - I чверті XVIII ст. Історикогеографічні дослідження в Україні. № 8. Київ: Інститут історії НАН України, 2005. С. 328.

16. Бакалець О.А. Талер в грошовому обігу України кінця XVI - першої чверті XVIII ст. Бар, 2004. C. 17.

17. Бакалець О.А. Українські літописи XVII - XVIII ст. про економіку та грошовий обіг Гетьманщини. Спеціальні історичні дисципліни. № 11. Ч. 1. Київ, 2004. С. 218-232.

18. Башинська Л.С. Монети Російської держави XVI-XVIII ст. у фондах БКМ. Юр’ївський літопис. № 14. Біла Церква, 2015. C. 105-115.

19. Бєлая О. Архівні джерела про монетні скарби Києва. Пам'ятки. Археографічний щорічник. № 14. Київ, 2013. C.189-194. 
20. Бойко-Гагарін А.С. Намисто із шестигрошовиками, карбованими на львівському монетному дворі, найдене у Вінницькій області. Львівські нумізматичні записки. № 10. Львів, 2014. С.48.

21. Бойко-Гагарін А.С. Нове надходження до зібрання НМІУ - “севський чех” 1686 року. Нумізматика і Фалеристика. № 2. Київ, 2018. С.16-18.

22. Желіхівська Н.М. Батурин - один із торгівельних центрів Гетьманщини XVII - XVIII ст. Конотопські читання. Випуск IV. Конотоп, 2013. C. 13.

23. Зразюк 3.О. Монетні скарби першої половини XVII ст. 3 території Правобережної України (сучасна територія Київської та Житомирської областей). Тематичний збірник наукових праць. Національному музею історії України - 110. Частина 1. Київ, 2009. С. 159.

24. Козубовський Г.А. Проблема карбування власної монети в Україні в XVII ст. Магістеріум. Археологічні студії. Вип. 6. Київ: Києво-Могилянська академія, 2001. С. 39.

25. Котляр М.Ф. Грошовий обіг на території України доби Феодалізму. Київ: Наукова думка, 1971. 174 с.

26. Котляр М.Ф. Нариси історії обігу й лічби монет на Україні XIV - XVIII ст. Київ: Наукова Думка, 1981. С. 3.

27. Коцур В. Знахідки золотих дукатів в Україні - проблеми та перспективи дослідження. Studia I Materialy «Forum Numizmatyczne». № 2. Bialystok, 2016. S. 19.

28. Коцур В.П. Актуальні напрямки та організаційні засади сучасних досліджень середньовічної нумізматики в Україні. Наукові записки з української історії: Збірник наукових статей. Вип. 33. Переяслав-Хмельницький, 2013. С. 3.

29. Коцур В.П. Історіографія українського скарбознавства. Український Нумізматичний Щорічник. № 1. Київ, 2017. C. $15-32$.

30. Коцур В.П. Щодо проблеми використання матеріалів «чорної» археології в наукових дослідженнях з нумізматики. Тези доповідей IV міжнародної науково-практичної конференції «Актуальні проблеми нумізматики у системі спеціальних галузей історичної науки». 22-23 червня 2016 р. Кіровоград-Київ-Переяслав-Хмельницький, 2016. С. 11-14. 
31. Михальчишин I.Р., Вдовиченко А.М. До методології історичної науки. Тематичний збірник наукових праць «Національний музей історії України - скарбниця історичної пам'яті українського народу». Київ: «III, Лтд», 1999. С. 14-15.

32. Орлик B.M. Інформаційний потенціал WEB-ресурсів у нумізматичних дослідженнях (на прикладі монет держав Хрестоносців). Матеріали наукової конференції з міжнародною участю «Архівознавчі та джерелознавчі галузі знань: проблеми взаємодії на сучасному етапі». 14 березня 2013 р., м. Київ. Київ, 2013. С. 129-133.

33. Поворознюк К.В. Монетні скарби XV-XVIII ст. $з$ фондів Хмельницького обласного краєзнавчого музею (ХОКМ). Матеріали ХІІІ Подільської історико-краєзнавчої конференції. 18-19 листопада 2010 р. Кам'янець-Подільський: Абетка, 2010. C. 98 .

34. Попельницька О. Нумізматично-речові скарби як історичне джерело (на прикладі скарбу XVI-XVII століття 3 села Старосілля). Спеціальні історичні дисципліни: питання теорії та методики. Число 11. Частина 1. Київ, 2004. С. 204.

35. Попельницька О. Речовий скарб XVII ст. з с. Новоселиці. Вісник. № 1 (3). Київ: Українське товариство охорони пам’яток історії та культури, 1999. С. 59.

36. Рябцевич В.Н., Титок В.А. Русская монетная медь XVII века в кладах Белоруссии и Украины. Доклады к конференции по археологии Белоруссии (март 1969). Древности Белоруссии. Минск, 1969. С. 434.

37. Сементовский Н. Запорожская рукопись указывающая в каких именно местах и какие сокрыты клады гайдамаками и местными жителями. Киев: Типография А. Гаммершмида, 1857. С. 15.

38. Синчук И.И. Почему полтораков больше на украинских землях? Збірник наукових праць. Грошовий обіг і банківська справа в Україні: минуле та сучасність. Львів, 2005. С. 201.

39. Смирнов М.И. Архивный фонд Петербургского монетного двора: история и современное состояние. Тезисы докладов и сообщений «Всероссийская нумизматическая конференция». Вологда, 18-21 мая 1993 г. - Вологда: ЛиС, 1993. C. $80-83$. 
40. Швидько Г. Джерела до історії Гетьманщини в архіві зовнішньої політики Росії. Третій міжнародний конгрес україністів. 26-29 серпня 1996 р., Історія. Частина 1. Харків, 1996. С. 89-92.

41. Шпортун О. Нумізматичні веб-сайти України. Studia I Materialy «Forum Numizmatyczne, Pieniadz I Mennice». № 1. Bialystok, 2016. S. 174.

42. Шпортун О. Проблеми використання сайту «Auction.violity.com» в нумізматичних дослідженнях. Збірник праць IV Міжнародної науково-практ конференції «Актуальні проблеми нумізматики в системі допоміжних історичних дисциплін». 22-23 червня 2016 р. Кіровоград-Київ-ПереяславХмельницький, 2016. С. 125-127.

43. Шугаевский В.А. О научном значении монетных находок. С.-Петербург, 1911. С. 17.

44. Шуст Р. М. Севські чехи. Енциклопедія історії України : у 10 т. / редкол.: В. А. Смолій (голова) та ін. ; Інститут історії України НАН України. К.: Наукова думка, 2012. Т. 9: С. 503. 45. Шуст P.M. Що носили в гаманцях козаки війська Богдана Хмельницького? Грошовий обіг і банківська справа в Україні: минуле та сучасність. Львів, 2005. С. 214.

46. Яушева-Омельянчик Р.М. Монеты Польши и Московского государства в кладах Украины (на материалах Национального музея история Украины). Materialy z I Miedzynarodowej Konferencji Numizmatycznej. Bialorus, Litwa, Polska, Ukraina wspolne dzieje pieniadza. Suprals, 20-22.X.1994. Warszawa, 1996. S. 101.

47. Аукціон New Auction. URL: https://newauction.com.ua/ (дата звернення: 03.10.2018 p.).

48. Аукціон UNC. URL: https:/unc.ua/ (дата звернення: 03.10.2018 p.).

49. Гетьманщина або Військо Запорозьке. URL: https://uk.wikipedia.org/wiki/Гетьманщина або Військо Запорозьке (дата звернення 03.10.2018 р.).

50. Економіка Гетьманщини. URL: https://uk.wikipedia.org/ wiki/ Економіка Гетьманщини (дата звернення: 03.10.2018 р.).

51. Севський чех. URL: https://uk.wikipedia.org/wiki/ Севський чех (дата зверненя: 03.10.2018 p.). 


\section{REFERENCES}

1. Bajvidovich, O. (2015, September 9). Na Podole obnaruzhili ruslo i pol'skie monety. Vesti [Kiev], p. 3 [in Russian].

2. Bakalets, O. A. (2004). Ukrainski litopysy XVII - XVIII st. pro ekonomiku ta hroshovyi obih Hetmanshchyny. Spetsialni istorychni dystsypliny. 1(11). 218-232 [in Ukrainian].

3. Bakalets, O. A. (2005) Rosiiska sribna kopiika v hroshovomu obihu Ukrainy II polovyny XVII - I chverti XVIII st. Istorykoheohrafichni doslidzhennia v Ukraini. (8). 328 [in Ukrainian].

4. Bakalets, O. A. (2006). Hroshi ta hroshovyi obih na Podilli XVII-XVIII st. Spetsialni istorychni dystsypliny. (13). 121 [in Ukrainian].

5. Bakalets, O. A. (2009). Velyko-Bushivskyi skarb 2004 r. zakhidnoievropeiskykh monet XVII st. Istoryko-heohrafichni doslidzhennia v Ukraini. (11). 200 [in Ukrainian].

6. Bakalets, V. A. (2004). Taler $v$ hroshovomu obihu Ukrainy kintsia XVI - pershoi chverti XVIII st. Bar [in Ukrainian].

7. Bashynska, L. S. (2015). Monety Rosiiskoi derzhavy XVIXVIII st. $\mathrm{u}$ fondakh BKM. Yurivskyi litopys. 14. 105-115 [in Ukrainian].

8. Bielaia, O. M. (2013). Arkhivni dzherela pro monetni skarby Kyieva. Pam'iatky. Arkheohrafichnyi shchorichnyk. (14). 189-194 [in Ukrainian].

9. Bkalets, O. A. (2007). Monetni skarby yak dzherelo vyvchennia hroshovoho obihu Hetmanshchyny (1648-1764 rr.) (Doctoral dissertation). avtoref. dys. na zdobuttia nauk. stupenia kandydata ist. nauk: spets. 07.00.06. Kyiv. Ukraina [in Ukrainian].

10. Boiko-Haharin, A. S. (2014). Namysto iz shestyhroshovykamy, karbovanymy na lvivskomu monetnomu dvori, naidene u Vinnytskii oblasti. Lvivski numizmatychni zapysky. (10). 48 [in Ukrainian].

11. Boiko-Haharin, A. S. (2018). Nove nadkhodzhennia do zibrannia NMIU - «sevskyi chekh» 1686 roku. Numizmatyka i falerystyka. 2. 16-18. [in Ukrainian].

12. Jausheva-Omel'janchik, R. (1996). Monety Pol'shi $i$ Moskovskogo gosudarstva v kladah Ukrainy (na materialah Nacional'nogo muzeja istorija Ukrainy). In Materialy z I 
Miedzynarodowej Konferencji Numizmatycznej. Bialorus, Litwa, Polska, Ukraina wspolne dzieje pieniadza (p. 101). Suprasl, Poland [in Russian].

13. Kotliar, M.F. (1971). Hroshovyi obih na terytorii Ukrainy doby feodalizmu. Kyiv [in Ukrainian].

14. Kotliar, M.F. (1981). Narysy istorii obihu y lichby monet na Ukraini XIV - XVIII st. Kyiv [in Ukrainian].

15. Kotsur, V. P. (2013). Aktualni napriamky ta orhanizatsiini zasady suchasnykh doslidzhen serednovichnoi numizmatyky $\mathrm{v}$ Ukraini. Naukovi zapysky z ukrainskoi istorii. 33. 1-10. [in Ukrainian].

16. Kotsur, V. P. (2016). Shchodo problemy vykorystannia materialiv «chornoi» arkheolohii v naukovykh doslidzhenniakh z numizmatyky. In Aktualni problemy numizmatyky u systemi spetsialnykh haluzei istorychnoi nauky (pp. 11-14). KirovohradKyiv-Pereiaslav-Khmelnytskyi [in Ukrainian].

17. Kotsur, V. P. (2016). Znakhidky zolotykh dukativ v Ukrainiproblemy ta perspektyvy doslidzhennia. In Forum numizmatyczne: pieniądz i mennice: studia i materiały (2nd ed., p. 19). Bilostok [in Ukrainian].

18. Kotsur, V. P. (2017). Istoriohrafiia ukrainskoho skarboznavstva. Ukrainskyi Numizmatychnyi Shchorichnyk. 1. 15-32 [in Ukrainian].

19. Kozubovskyi, H. A. (2001). Problema karbuvannia vlasnoi monety v Ukraini v XVII st. Mahisterium. Arkheolohichni studii. 6. 39 [in Ukrainian].

20. Mykhalchyshyn, I. R., \& Vdovychenko, A. M. (1999). Do metodolohii istorychnoi nauky. In Natsionalnyi muzei istorii Ukrainy - skarbnytsia istorychnoi pam'iati ukrainskoho narodu (pp. 14-15). Kyiv: III, Ltd. [in Ukrainian].

21. Orlyk, V. M. (2013). Informatsiinyi potentsial WEB-resursiv u numizmatychnykh doslidzhenniakh (na prykladi monet derzhav Khrestonostsiv). In Arkhivoznavchi ta dzhereloznavchi haluzi znan: problemy vzaiemodii na suchasnomu etapi (pp. 129-133). Kyiv. [in Ukrainian].

22. Popelnytska, 0. (1999). Rechovyi skarb XVII st. z s. Novoselytsi. Visnyk. Ukrainske tovarystvo okhorony pamiatok istorii ta kultury. 3. 59 [in Ukrainian]. 
23. Popelnytska, O. (2004). Numizmatychno-rechovi skarby yak istorychne dzherelo (na prykladi skarbu XVI-XVII stolittia z sela Starosillia). Spetsialni istorychni dystsypliny: pytannia teorii ta metodyky. 1(11). 204 [in Ukrainian].

24. Povorozniuk, K. V. (2010). Monetni skarby XV-XVIII st. z fondiv Khmelnytskoho oblasnoho kraieznavchoho muzeiu (KhOKM). In Materialy KhIII Podilskoi istoryko-kraieznavchoi konferentsii (p. 98). Kam'ianets-Podilskyi: Abetka [in Ukrainian].

25. Rjabcevich, V. N., Titok, V. A. (1969). Russkaja monetnaja med'XVII veka v kladah Belorussii i Ukrainy. Drevnosti Belorussii: Doklady k Konferencii po arheologii Belorussii. (Mart 1969) (p. 434) [in Russian].

26. Sementovskij, M. (1857). Zaporozhskaja rukopis' ukazyvajushhaja $v$ kakih imenno mestah $i$ kakie sokryty klady gajdamakami $i$ mestnymi zhiteljami. Kiev: Tipografija A. Gammershmida [in Russian].

27. Shportun, O. (2016). Numizmatychni veb-saity Ukrainy. In Forum Numizmatyczne, Pieniadz I Mennice (p. 174). Bialystok [in Ukrainian].

28. Shportun, O. (2016). Problemy vykorystannia saitu «Auction.violity.com» v numizmatychnykh doslidzhenniakh. In Aktualni problemy numizmatyky $\mathrm{v}$ systemi dopomizhnykh istorychnykh dystsyplin (pp. 125-127). Kirovohrad-KyivPereiaslav-Khmelnytskyi [in Ukrainian].

29. Shugaevskij, V. A. (1911). O nauchnom znachenii monetnyh nahodok. Sankt-Peterburg [in Russian].

30. Shust, R. M. (2012). Sevski chekhy. In Entsyklopediia istorii Ukrainy (Vol. 9, p. 503). Kyiv: Instytut istorii NANU [in Ukrainian].

31. Shust, R.M. (2005) Shcho nosyly v hamantsiakh kozaky viiska Bohdana Khmelnytskoho? Abstract of papers: Hroshovyi obih i bankivska sprava v Ukraini: mynule ta suchasnist. (pp. 214). Lviv [in Ukrainian].

32. Shvydko, H. (1996). Dzherela do istorii Hetmanshchyny v arkhivi zovnishnoi polityky Rosii. In Tretii mizhnarodnyi konhres ukrainistiv. 26-29 serpnia 1996 r., Istoriia (pp. 89-92). Kharkiv [in Ukrainian]. 
33. Sinchuk, I.I. (2005) Pochemu poltorakov bol'she na ukrainskih zemljah? Groshovij obig i bankivs'ka sprava v Ukraïni: minule ta suchasnist' (p. 201). L'viv [in Ukrainian].

34. Smirnov, M. I. (1993). Arhivnyj fond Peterburgskogo monetnogo dvora: istorija i sovremennoe sostojanie. In Vserossijskaja numizmaticheskaja konferencija (pp. 80-83). Moskva [in Russian].

35. Zhelikhivska, N. M. (2013). Baturyn - odyn iz torhivelnykh tsentriv Hetmanshchyny XVII - XVIII st. Konotopski chytannia. 4. 13 [in Ukrainian].

36. Zraziuk, Z. O. (2009). Monetni skarby pershoi polovyny XVII st. z terytorii Pravoberezhnoi Ukrainy (suchasna terytoriia Kyivskoi ta Zhytomyrskoi oblastei). In Tematychnyi zbirnyk naukovykh prats. Natsionalnomu muzeiu istorii Ukrainy (p. 159). Kyiv: Natsionalnyi muzei istorii Ukrainy [in Ukrainian].

\section{АНОТАЦІЯ}

Основними джерелами, що можуть бути використані у вивченні теми історії грошового обігу Гетьманщини у період з 1648 по 1764 роки, є: матеріали архівів, літописи, актові матеріали, етнографічні джерела, скарби, матеріали музейних колекиії, газетні матеріали, Інтернет-ресурси та приватні зібрання. Кожне з зазначених джерел має різну ступінь наукової корисності та достовірності. Значна кількість тогочасних актових матеріалів, літописів та етнографічних джерел вже досліджено українськими науковиями. Значним науковим потенціалом володіють державні історичні архіви. Зокрема, досліджуючи фонди Центрального державного історичного архіву в місті Києві нам вдалось встановити нові факти та надати подальшого розвитку вивченню аспекту фальшивомонетництва в Украӥні y XVIII століття. Інтернет-ресурси дозволяють виявити монети раніше неописаних штемпельних різновидів, а також розширити наме уявлення про вже складені топографіі знахідок монет. Актуальним в сучасній нумізматииі є введення в науковий обіг нових знайдених скарбів та їх склад, а також дослідження музейних зібрань. Нерідко колекиії музеїв формуються за рахунок дарунків місиевих жителів з монет, 
щуо були виявлені в тій самій історичній місцевості, щзо визначає колекиї історичних та краєзнавчих музеїв як високо інформативні у вивченні грошового обігу. Особливо изе музейні заклади, розмішені в географічних межах Гетьманщини, а також ті монети та скарби, щзо були знайдені та передані до інших музеїв. Незафіксовані більшістю попередніх дослідників є скарби, щзодо яких повідомлялось на сторінках періодичної преси. Так нам вдалось виявити повідомлення про скарби монет досліджуваного періоду на сторінках украӥнських газет дорадянського періоду та сучасності. Щодо приватних колекції, варто із певною обережністю вводити їх в науковий обіг, зважуючи на те, щзо, на жаль, далеко не всі колекціонери, збираючи колекиії, фіксують важливу для науковців інформачію.

Ключові слова: Гетьманщина, грошовий обіг, джерела вивчення, матеріали державних архівів, скарби, газетні публікаиії, музейні зібрання.

\section{АННОТАЦИЯ}

Основными источниками, которые могут быть использованы в изучении темы истории денежного обращения Гетманшины в период с 1648 по 1764 г2, являются: материаль архивов, летописи, актовые материаль, этнографические источники, материаль музейных коллекции, газетные материаль, Интернет-ресурсы и частные собрания. Каждый из указанных источников имеет разную степень научной полезности и достоверности. Значительное количество актовых материалов, летописей и этнографических источников уже исследовано украинскими учеными. Значительным научным потенцииалом обладают государственные исторические архивы. В частности, исследуя фонды Центрального государственного исторического архива в Киеве нам удалось установить новые факты в изучении аспекта фальиивомонетничества в Украине в XVIII веке. Интернет-ресурсы позволяют вылвить монеты ранее неописанных итемпельных разновидностей, а также расширить наше представление об уже составленной топографии находок монет. Актуальным в современной 
нумизматике является введение в научный оборот новых найденных сокровищ и их состав, а также исследования музейных собраний. Нередко коллекичи музеев формируются за счет подарков местных жителей из монет, обнаруженных в той же исторической местности. Особенно это музейные учреждения, расположенные в географических границах Гетманшины, а также те монеты и сокровища, которые были найдень и передань в другие музеи. Так нам удалось выявить сообщение о кладах монет исследуемого периода на страницах украинских газет досоветского периода и современности. Частные коллекции, стоит с определенной осторожностью вводить в научный оборот, посылаясь на то, что, к сожалению, далеко не все коллекционеры, собирая коллекиии, фиксируют важную для ученых информацию.

Ключевые слова: Гетманщинн, денежное обращзение, источники изучения, материаль государственных архивов, сокровища, газетные публикачии, музейные собрания.

Надійшла до редакиії: 03.10.2018 p. Прийнята до друку: 02.11.2018 p. 